\title{
Effect of penehyclidine hydrochloride on IL-6, TNF- $\alpha$, HIF- $1 \alpha$ and oxidative stress in lung tissue of young rats with acute lung injury
}

\author{
Jihong Shu', Zhenjiao Fang ${ }^{2}$, Xinjun Xiong ${ }^{3 *}$ \\ ${ }^{1}$ Department of Pediatrics, ${ }^{2}$ Department of Outpatient Office, ${ }^{3}$ Department of Respiratory Medicine, Hanchuan People's \\ Hospital, Hanchuan, PR China
}

*For correspondence: Email: pca11n@163.com

Sent for review: 16 April 2020

Revised accepted: 27 June 2020

\begin{abstract}
Purpose: To investigate the effect of penehyclidine hydrochloride (PHC) on interleukin-6 (IL-6), tumor

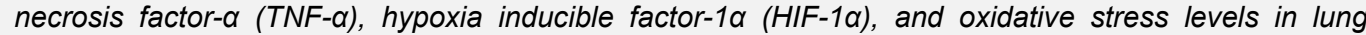
tissues of acute lung injury (ALI) neonatal rats.

Methods: 40 male Sprague-Dawley (SD) rats were assigned to model, low-dose PHC, high-dose PHC, and control groups $(n=10)$. Levels of IL-6, TNF- $\alpha$ and HIF-1 $\alpha$ were evaluated by enzyme-linked immunosorbent assay (ELISA). Pulmonary lesions were determined histologically using H\&E staining. Results: The lung tissue levels of IL-6, TNF- $\alpha$ and HIF-1 $\alpha$ were significantly higher in model rats than in control rats, and significantly lower in PHC-treated rats than in model group, with decrease in levels as PHC dose increased $(p<0.05)$. The lung tissue activity of MPO and level of MDA in model rats were significantly higher than those in control rats, but significantly lower in the lung tissues of the two PHC groups than in the model group; decrease in levels occurred as PHC dose increased $(p<0.05)$.

Conclusion: PHC decreases the lung and serum levels of IL-6, TNF- $\alpha$ and HIF-1 $\alpha$ in a rat model of ALI, and mitigates pulmonary oxidative stress and lung tissue damage. Thus, penehyclidine hydrochloride may be useful to mitigate ALI-induced damage in patients. However, further studies and clinical trials are required to ascertain this
\end{abstract}

Keywords: Penehyclidine hydrochloride, Alveolar septum, Acute lung injury, Inflammatory cells, IL-6, TNF- $\alpha$, HIF-1 $\alpha$, Oxidative stress

\begin{abstract}
This is an Open Access article that uses a fund-ing model which does not charge readers or their institutions for access and distributed under the terms of the Creative Commons Attribution License (http://creativecommons.org/licenses/by/4.0) and the Budapest Open Access Initiative (http://www.budapestopenaccessinitiative.org/read), which permit unrestricted use, distribution, and reproduction in any medium, provided the original work is properly credited.

Tropical Journal of Pharmaceutical Research is indexed by Science Citation Index (SciSearch), Scopus, International Pharmaceutical Abstract, Chemical Abstracts, Embase, Index Copernicus, EBSCO, African Index Medicus, JournalSeek, Journal Citation Reports/Science Edition, Directory of Open Access Journals (DOAJ), African Journal Online, Bioline International, Open-J-Gate and Pharmacy Abstracts
\end{abstract}

\section{INTRODUCTION}

Acute lung injury (ALI) is a major manifestation of systemic inflammatory response syndrome in the lungs. It refers to injuries in cells of alveolar epithelium and capillary endothelium caused directly and indirectly by pneumonia, sepsis, drowning, fat embolism, alveolar hemorrhage and toxic gas inhalation [1]. The disease (ALI) is associated with pathophysiological characteristics such as reduction in lung volume, decrease in pulmonary compliance, impairment of ventilation/blood flow homeostasis, and clinical symptoms such as hypoxemia and respiratory difficulties, which could seriously induce acute respiratory distress syndrome and multiple organ 
failure [2]. At the present, ALI is treated via drug intervention. However, the non-specific nature of traditional anti-cholinergic drugs leads to adverse reactions and unsatisfactory clinical curative effects which limit their use [3]. Penehyclidine hydrochloride $(\mathrm{PHC})$ is a highly-selective anticholinergic agent. It selectively stimulates M1 and $\mathrm{M} 3$ receptors, but it has no obvious effect on M2. The M3 receptors are present in airway smooth muscle [4]. It has been demonstrated that PHC protects the cells by improving microcirculation, reducing the release of lysosomes, and decreasing the permeability of the capillary wall, and it is associated with prolonged action time and low adverse effects [5]. This study was carried out to investigate the effect of PHC on IL-6, TNF- $\alpha$, HIF-1 $\alpha$ and oxidative stress status in pulmonary tissues of neonatal ALI rats.

\section{EXPERIMENTAL}

\section{Animals}

Forty male SD rats (mean age $=3.15 \pm 0.25$ days, and mean body weight $=12.26 \pm 2.12 \mathrm{~g}$ ), were raised at room temperature of $22-24{ }^{\circ} \mathrm{C}$, relative humidity of $40-60 \%$, and noise level of about $45 \mathrm{~dB}$. The young rats were fasted for $12 \mathrm{~h}$ prior to the experiment, but normal drinking water was freely given.

This study received approval from the Animal Ethics Section of Department of Respiratory Medicine, Hanchuan People's Hospital, 1 Renmin Avenue, Hanchuan City, Hubei Province. The study was implemented in line with $\mathrm{NIH}$ requirements for care of laboratory animals [6].

\section{Treatments}

Four groups of rats were used (10/group). There were no statistically significant differences in age and other general data among the three groups $(p>0.05)$. Model rats received normal saline at a dose of $1 \mathrm{ml} / \mathrm{kg}$, $30 \mathrm{~min}$ before injection of LPS at a dose of $5 \mathrm{mg} / \mathrm{kg}$ through the tail vein. Low-dose and high-dose $\mathrm{PHC}$ rats received $\mathrm{PHC}$ i.v. (0.3 and $1 \mathrm{mg} / \mathrm{kg}$, respectively), $30 \mathrm{~min}$ prior to LPS injection of LPS $(5 \mathrm{mg} / \mathrm{kg})$ via the tail vein. In the control group, normal saline was injected at a dose of $1 \mathrm{ml} / \mathrm{kg}$ into the abdominal cavity and the tail vein.

\section{Collection and preparation of serum and lung tissue samples}

Six hours after ALI model was established, $5 \mathrm{~mL}$ of arterial blood was taken from the left ventricle of each rat under intraperitoneal anesthesia, and centrifuged for $10 \mathrm{~min}$ at $2000 \mathrm{rpm}$. The serum samples were carefully separated, and kept at $20{ }^{\circ} \mathrm{C}$ in a refrigerator prior to subsequent analysis. Moreover, tissue homogenates (5\%) of the right lung lobes of the rats were prepared in normal saline.

\section{Biochemical assays}

Serum IL-6, TNF- $\alpha$ and HIF-1 $\alpha$ were determined with ELISA (ELISA kit, Elabscience, Wuhan, China), while the activities of MPO and SOD, and MDA levels in lung tissue were determined spectrophotometrically $(450 \mathrm{~nm}$, Intelligent microplate reader, Yunkelong, Wuhan, China).

\section{Histological examination of pulmonary tissue sections}

Slices of the upper lobe of the right lung were fixed in $4 \%$ paraformaldehyde and $4 \%$ pentanediol solution. After H\&E staining, morphological changes in the lung tissue were observed under a light microscope, and photographed.

\section{Statistical analysis}

Measurement data are expressed as mean \pm standard deviation (SD). Inter-group comparison was done using $t$-test. Count data are presented as percentage (\%), and inter-group comparison was carried out using $X^{2}$ test. All statistical analyses were done with SPSS 20.0 software package. Values of $p<0.05$ were considered statistically significant.

\section{RESULTS}

\section{Levels of IL-6, TNF- $\alpha$ and HIF-1 $\alpha$ in rat lung tissues}

As shown in Table 1, the levels of IL-6, TNF- $\alpha$ and HIF-1 $\alpha$ in lungs tissue of model neonatal rats were markedly upregulated, relative to control rat values, and were markedly lower in the lung tissue of the two PHC-treated groups than in the model group, with decreases in levels as $\mathrm{PHC}$ dose increased $(p<0.05)$.

\section{Lung MPO and superoxide dismutase activities, and malondialdehyde levels}

Lung level of MDA, and MPO activity were significantly higher in model rats than in controls, but they were lower in lung tissues of the PHCtreated rats than in model rats, and decreased with increase in PHC dose $(p<0.05)$. Lung tissue SOD activity was markedly lower in the model group than in the control group, but was 
significantly elevated, relative to model rats, and rose with increase in $\mathrm{PHC}$ dose (Table 2).

Table 1: IL-6, TNF- $\alpha$ and HIF-1 $\alpha$ levels in rat lung tissues $(n=10)$

\begin{tabular}{|c|c|c|c|}
\hline Group & $\begin{array}{c}\text { IL-6 } \\
\text { (ng/L) }\end{array}$ & $\begin{array}{l}\text { TNF- } \alpha \\
\text { (pg/mL) }\end{array}$ & $\begin{array}{c}\text { HIF-1a } \\
\text { (pg/mL) }\end{array}$ \\
\hline Control & $\begin{array}{c}65.16 \pm \\
9.12\end{array}$ & $76.15 \pm 9.15$ & $\begin{array}{c}521.31 \pm \\
25.12\end{array}$ \\
\hline Model & $\begin{array}{c}188.43 \pm \\
32.10^{\mathrm{a}}\end{array}$ & $\begin{array}{c}144.12 \pm \\
20.43^{\mathrm{a}}\end{array}$ & $\begin{array}{c}912.17 \pm \\
40.65^{a}\end{array}$ \\
\hline $\begin{array}{l}\text { Low dose } \\
(0.3 \mathrm{mg} / \mathrm{kg})\end{array}$ & $\begin{array}{c}134.16 \pm \\
14.86^{\mathrm{ab}}\end{array}$ & $\begin{array}{c}115.46 \pm \\
15.43^{\mathrm{ab}}\end{array}$ & $\begin{array}{c}849.26 \pm \\
30.25^{\mathrm{ab}}\end{array}$ \\
\hline $\begin{array}{l}\text { High dose } \\
(1 \mathrm{mg} / \mathrm{kg})\end{array}$ & $\begin{array}{l}110.35 \pm \\
10.44^{\mathrm{abc}}\end{array}$ & $\begin{array}{l}90.17 \pm \\
12.75^{\mathrm{abc}}\end{array}$ & $\begin{array}{l}712.15 \pm \\
20.33^{\mathrm{abc}}\end{array}$ \\
\hline
\end{tabular}

Data are presented as mean \pm SD. ${ }^{a} P<0.05$, vs control; ${ }^{b} p<0.05$, vs model rats, ${ }^{c} p<0.05$, vs lowdose $\mathrm{PHC}$ rats

Table 2: Lung MDA level and activities of MPO and SOD in rats $(n=10)$

\begin{tabular}{lccc}
\hline Group & MDA & SOD & MPO \\
\hline Control & $0.73 \pm$ & $134.16 \pm$ & $0.76 \pm$ \\
& 0.12 & 14.25 & 0.12 \\
Model & $1.26 \pm$ & $91.45 \pm$ & $1.34 \pm$ \\
Low dose & $0.21^{\mathrm{a}}$ & $11.53^{\mathrm{a}}$ & $0.25^{\mathrm{a}}$ \\
$(0.3 \mathrm{mg} / \mathrm{kg})$ & $0.96 \pm$ & $112.76 \pm$ & $0.98 \pm$ \\
High dose $(1$ & $0.86 \pm$ & $20.46^{\mathrm{ab}}$ & $0.12^{\mathrm{ab}}$ \\
$\mathrm{mg} / \mathrm{kg})$ & $0.08^{\mathrm{abc}}$ & $120.73 \pm$ & $0.86 \pm$ \\
\hline
\end{tabular}

Data are presented as mean \pm SD. ${ }^{a} P<0.05$, vs control; ${ }^{b} p$, vs model rats, ${ }^{c} p<0.05$, vs low-dose PHC rats

\section{Serum IL-6, TNF- $\alpha$ and HIF-1 $\alpha$ levels}

Table 3 shows that serum levels of IL-6, TNF- $\alpha$ and HIF-1 $\alpha$ in the model group were upregulated in model rats, relative to control rats, but were significantly lower in PHC-treated groups than in model rats, and diminished with increase in PHC dose $(p<0.05)$.

Table 3: Serum IL-6, TNF- $\alpha$ and HIF-1 $\alpha$ levels in rats $(\mathrm{n}=10)$

\begin{tabular}{lccc}
\hline Group & $\begin{array}{c}\text { IL-6 } \\
(\mathbf{n g} / \mathrm{L})\end{array}$ & $\begin{array}{c}\text { TNF-a } \\
(\mathrm{pg} / \mathrm{mL})\end{array}$ & $\begin{array}{c}\text { HIF-1a } \\
(\mathbf{p g} / \mathrm{mL})\end{array}$ \\
\hline \multirow{2}{*}{ Control } & $53.16 \pm$ & $46.53 \pm$ & $423.51 \pm$ \\
& 8.15 & 10.33 & 24.46 \\
Model & $176.43 \pm$ & $104.16 \pm$ & $853.26 \pm$ \\
& $11.43^{\mathrm{a}}$ & $18.46^{\mathrm{a}}$ & $38.22^{\mathrm{a}}$ \\
Low dose & $125.18 \pm$ & $86.59 \pm$ & $764.15 \pm$ \\
(0.3mg/kg) & $13.76^{\mathrm{ab}}$ & $6.15 \mathrm{ab}$ & $25.46^{\mathrm{ab}}$ \\
High dose & $86.19 \pm$ & $62.14 \pm$ & $683.19 \pm$ \\
(1 $\mathrm{mg} / \mathrm{kg})$ & $9.46^{\mathrm{abc}}$ & $8.43^{\mathrm{abc}}$ & $20.13^{\mathrm{abc}}$ \\
\hline
\end{tabular}

Results are presented as mean \pm SD. ${ }^{a} P<0.05$, vs control; ${ }^{b} p<0.05$, vs model group, ${ }^{c} p<0.05$, vs lowdose $\mathrm{PHC}$ rats

\section{Morphological features of rat lung tissues}

Lung tissue morphology in the control group was normal, with intact alveolar wall structure devoid of blisters in the lung interstitium. Moreover, there were no inflammatory cells and red blood cells. In the model group, the alveolar wall was severely damaged: the alveolar septum was widened, with diffuse edema, large number of inflammatory cells, and red blood cell exudation. In contrast, the alveolar wall structure of rats in low-dose PHC rats was more intact than that of the model group, with partial necrosis, slightly wider alveolar septum, and a low amount of inflammatory cells and red blood cell exudation. In the high-dose PHC group, the alveolar wall was relatively intact, with mild septal edema, and only a small population of inflammation-related cells. There was no red blood cell exudation in this group. These results are shown in Figure 1.
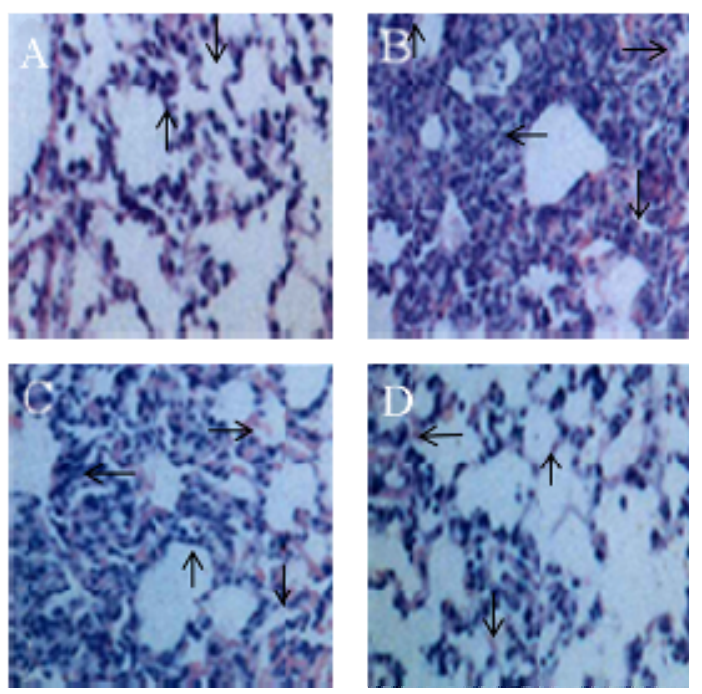

Figure 1: Comparison of lung tissue morphologies among the various rat groups. A: pulmonary tissue of rats in the control group; B: pulmonary tissue of rats in the model group; $\mathrm{C}$ : pulmonary tissue of young rats in the low-dose PHC group; D: pulmonary tissue of young rats in the high-dose $\mathrm{PHC}$ group.

\section{DISCUSSION}

It is known that ALI is a clinical syndrome caused by various internal and external factors other than cardiogenic factors. The disease is associated with presence of large amounts of neutrophils, cytokine over-expression, oxidative stress, coagulation and anticoagulation, and imbalance in apoptosis status. These factors lead to severe inflammatory response and increased vascular permeability, reduction in lung compliance, decreases in lung volume, and abnormal ventilation/perfusion ratio [7]. The disease is a serious aliment usually associated 
with rapid escalation and high mortality. Therefore, it is vital to develop effective and rapid-acting drugs for the treatment of the disease and reduction of the associated complications.

Penehyclidine hydrochloride (PHC) is a new cholinergic receptor blocker which has antioxidant and cell protective effects [8]. Recent studies have found that PHC reduces lipid peroxidation, protects cellular structure, stabilizes biological membranes, does not excite $\mathrm{M}_{2}$ subtype, has no effect on the heart, and reduces the adverse reactions of traditional anti-cholinergic drugs [9]. Results from histology revealed that pulmonary tissues of control rats had normal alveolar wall structure, without blisters in the lung interstitial cells or inflammatory cells or red blood cells. In the model group, the alveolar wall was severely damaged, with widened alveolar septum, diffuse edema, and large population of inflammatory cells and red blood cell exudates. In contrast, alveolar wall structure in the lowdose PHC group was more intact than that in the model group, with partial necrosis, slightly wider alveolar septum, and smaller amounts of inflammatory cells and red blood cell exudation.

In the high-dose group, the alveolar walls were relatively intact, with mild edema in the alveolar septum, and only a small population of inflammatory cells, but no red blood cell exudation. These results suggest that PHC alleviated lung injury in ALI rats. This mitigative effect may be related to the anti-spasmodic effect of PHC, decreases in permeability of pulmonary capillary wall, and inhibition of the release of inflammatory mediators and cytokines.

Interleukin-6 is a cytokine produced by macrophages, $T$ lymphocytes, B lymphocytes and various tumor cells [10]. It stimulates the proliferation and differentiation of cells involved in immune response. It is known that TNF- $\alpha$ is involved in normal inflammatory and immune responses [11]. The level of TNF- $\alpha$ is increased in sepsis, malignant tumor, heart failure, chronic inflammatory disease and other pathological states [12]. Hypoxia-inducible factor-alpha (HIF$1 \alpha$ ) is a hypoxia-inducible binding protein produced under hypoxic conditions. High levels of HIF-1 $\alpha$ induce the production of inflammatory factors such as IL-6 and TNF- $\alpha$, thereby aggravating inflammatory response [13].

In this study, serum and lung levels of IL-6, TNF$\alpha$ and HIF-1 $\alpha$ in young model rats were markedly upregulated, relative to control levels. Moreover, IL-6, TNF- $\alpha$ and HIF-1 $\alpha$ levels in the lung tissue and serum of the two groups treated with PHC were significantly lower than the corresponding value in model rats, and decreased with increase in PHC dose. These findings suggest that PHC reduced inflammatory reaction in lung tissue and serum in the young rat model of ALI, thereby reducing lung injury and alleviating ALI symptoms.

The accumulation of a large number of neutrophils in alveolar cavity is one of the characteristic changes in ALI. The activity of myeloperoxidase (MPO), a redox marker enzyme in neutrophils, is used as an index of the accumulation of neutrophils in lung tissues [14]. Malondialdehyde (MDA) is a product of lipid peroxidation in cell membranes. The level of MDA is indirectly used for evaluation of the degree of damage to cell membranes by free radical-induced lipid peroxidation [15]. Superoxide dismutase (SOD) is a relatively ubiquitous antioxidant enzyme in humans. It neutralizes the superoxide anion free radical, thereby reducing damage to cells by oxygen free radicals. The antioxidant capacity of body tissues can be evaluated clinically by determining SOD activity [16].

In the present study, the activity of MPO and MDA level were higher in lung tissues of model rats than those in the control group, but they were significantly lower in PHC-treated rats than in model rats, and decreased with increase in PHC dose. Model rat pulmonary SOD activity was markedly lower than that in the control group. In contrast, SOD activity was significantly higher in the lung tissues of the two groups treated with $\mathrm{PHC}$ than in the model group, and it increased with increase in PHC dose. These results suggest that $\mathrm{PHC}$ reduced the aggregation of neutrophils in alveolar cavity, reduced oxygen free radical-induced damage to lung tissue cells, and exerted good antioxidant effects, thereby reducing ALI.

\section{CONCLUSION}

These results show that PHC reduces IL-6, TNF$\alpha$ and HIF-1 $\alpha$ levels in lung tissues and serum of young rats with ALI. Moreover, PHC reduces lung tissue oxidative stress, and alleviates ALIassociated lung tissue injury. Thus, penehyclidine hydrochloride may be used for mitigation of ALI-induced damage in patients.

\section{DECLARATIONS}

\section{Conflict of interest}

No conflict of interest is associated with this work. 


\section{Contribution of authors}

We declare that this work was done by the author(s) named in this article and all liabilities pertaining to claims relating to the content of this article will be borne by the authors. All authors read and approved the manuscript for publication. Xinjun Xiong conceived and designed the study, Jihong Shu, Zhenjiao Fang, Xinjun Xiong collected and analysed the data, while Jihong Shu wrote the manuscript.

\section{Open Access}

This is an Open Access article that uses a funding model which does not charge readers or their institutions for access and distributed under the terms of the Creative Commons Attribution License (http://creativecommons.org/licenses/by/ 4.0) and the Budapest Open Access Initiative (http://www.budapestopenaccessinitiative.org/rea d), which permit unrestricted use, distribution, and reproduction in any medium, provided the original work is properly credited.

\section{REFERENCES}

1. Chen $X Y$, Dou $Y X$, Luo $D D$, Zhang $Z B, L i C L$, Zeng $H F$, Su ZR, Xie JH, Lai XP, Li YC. $\beta$-Patchoulene from patchouli oil protects against LPS-induced acute lung injury via suppressing NF-KB and activating Nrf2 pathways. Int Immunopharmacol 2017; 50: 270-278.

2. Cao C, Yin C, Shou S, Wang J, Yu L, Li X, Chai Y. Ulinastatin Protects Against LPS-Induced Acute Lung Injury by Attenuating TLR4/NF-KB Pathway Activation and Reducing Inflammatory Mediators. Shock 2018; 50(5): 595-605.

3. Zhao J, Sun Z, You G, Wang Y, Chen G, Zhao L, Zhou H. Transfusion of Cryopreserved platelets exacerbates inflammatory liver and lung injury in a mice model of hemorrhage. J Trauma Acute Care Surg 2018; 85(2): 327-333.

4. Shu Y, Li Z, Han B. Penehyclidine hydrochloride postconditioning ameliorates cerebral ischemiareperfusion injury: critical role of mitochondrial ATP sensitive potassium channel. J Biol Regul Homeost Agents 2016; 30(1): 41-53.

5. Zheng F, Xiao F, Yuan QH, Liu QS, Zhang ZZ, Wang YL, Zhan J. Penehyclidine Hydrochloride Decreases Pulmonary Microvascular Endothelial Inflammatory Injury Through a Beta-Arrestin-1-Dependent Mechanism. Inflammation 2018; 41(5): 1610-1620.
6. World Health Organization. Principles of laboratory animal care. WHO Chron 1985; 39: 51-56.

7. Tong W. Basic and clinical research progress in acute lung injury/acute respiratory distress syndrome. Infect Int 2018; 7(2): 38-43.

8. Tian X, Xie G, Xiao H, Ding F, Bao W, Zhang M. CXCR4 knockdown prevents inflammatory cytokine expression in macrophages by suppressing activation of MAPK and NF-KB signaling pathways. Cell Biosci 2019; 9: 55.

9. Zhu R, Zhao Y, Li X, Bai T, Wang S, Wang $W$, Sun $Y$. Effects of penehyclidine hydrochloride on severe acute pancreatitis-associated acute lung injury in rats. Biomed Pharmacother 2018; 97: 1689-1693.

10. Swaroopa D, Bhaskar K, Mahathi T, Katkam S, Raju YS, Chandra N, Kutala VK. Association of serum interleukin 6, interleukin 8, and Acute Physiology and Chronic Health Evaluation II score with clinical outcome in patients with acute respiratory distress syndrome. Indian J Crit Care Med 2016; 20(9): 518-525.

11. Kumar $P$, Kumar A, Misra S, Sagar R, Faruq M, Suroliya $V$, Vivekanandhan S, Srivastava AK, Prasad K. Tumor necrosis factor-alpha (- 308G/A, + 488G/A, - 857C/T and $-1031 \mathrm{~T} / \mathrm{C})$ gene polymorphisms and risk of ischemic stroke in north Indian population: A hospital based case-control study. Meta Gene 2015; 7: 34-39.

12. Kang HS, Koo JS, Lee KM, Kim DB, Lee JM, Kim YJ, Yoon $H$, Jang HJ. Two-year delay in ulcerative colitis diagnosis is associated with anti-tumor necrosis factor alpha use. World J Gastroenterol 2019; 25(8): 9891001.

13. Takahara $Y$, Tokunou T, Kojima H, Hirooka Y, Ichiki $T$. Deletion of hypoxia-inducible factor-1a in myeloid lineage exaggerates angiotensin II-induced formation of abdominal aortic aneurysm. Clin Sci (Lond) 2017; 131(7): 609-620.

14. Ahuja A, Tyagi S, Seth T, Pati HP, Gahlot G, Tripathi P, Somasundaram V, Saxena $R$. Comparison of Immunohistochemistry, Cytochemistry, and Flow Cytometry in AML for Myeloperoxidase Detection. Indian $J$ Hematol Blood Transfus 2018; 34(2): 233-239.

15. Choi B, Ryu D, Kim Cl, Lee JY, Choi A, Koh E. Probabilistic dietary exposure to ethyl carbamate from fermented foods and alcoholic beverages in the Korean population. Food Addit Contam Part A Chem Anal Control Expo Risk Assess 2017; 34(11): 1885-1892.

16. Mirrahimi M, Hosseini V, Shakeri-Zadeh A, Alamzadeh Z, Kamrava SK, Attaran N, Abed Z, Ghaznavi H, Hosseini Nami SMA. Modulation of cancer cells' radiation response in the presence of folate conjugated $\mathrm{Au} @ \mathrm{Fe}_{2} \mathrm{O}_{3}$ nanocomplex as a targeted radiosensitizer. Clin Transl Oncol 2019; 21(4): 479-488. 